\title{
GIS Mapping of Land Slopes, Soil Depths, Erosian Classes, Large Soil Groups and Some Soil Properties: A Case Study of Kayseri Province in Turkey
}

\author{
M. Cüneyt Bağdatlı ${ }^{1, * i}$, Yiğitcan Ballı \\ ${ }^{1}$ Department of Biosystem Engineering, Engineering and Architecture Faculty, Nevsehir Hacı Bektas Veli University, Nevsehir, Turkey \\ ${ }^{2}$ Department of Environmental Engineering, Science Institute, Nevsehir Hac1 Bektas Veli University, Nevsehir, Turkey
}

Received July 6, 2021; Revised August 23, 2021; Accepted September 21, 2021

\section{Cite This Paper in the following Citation Styles}

(a): [1] M. Cüneyt Bağdatl, Yiğitcan Ballı, "GIS Mapping of Land Slopes, Soil Depths, Erosian Classes, Large Soil Groups and Some Soil Properties: A Case Study of Kayseri Province in Turkey," Universal Journal of Agricultural Research, Vol. 9, No. 5, pp. 166 - 175, 2021. DOI: 10.13189/ujar.2021.090503.

(b): M. Cüneyt Bağdatl, Yiğitcan Ball (2021). GIS Mapping of Land Slopes, Soil Depths, Erosian Classes, Large Soil Groups and Some Soil Properties: A Case Study of Kayseri Province in Turkey. Universal Journal of Agricultural Research, 9(5), 166 - 175. DOI: 10.13189/ujar.2021.090503.

Copyright@2021 by authors, all rights reserved. Authors agree that this article remains permanently open access under the terms of the Creative Commons Attribution License 4.0 International License

\begin{abstract}
This study was carried out to determine the spatial distribution of land slopes, soil depths, erosion classes, large soil groups and some soil properties by using Geography Information Systems (GIS) in Kayseri province (Turkey). As a result of the spatial analysis distributions; It has been observed that a large part of the province of Kayseri consists of soils with a depth of C class (50-90 m), and this area covers an area of $9443.95 \mathrm{~km}^{2}$. It is seen that the areas belonging to the $\mathrm{E}$ class $(0-20 \mathrm{~m})$ soil depth group are very few and this soil depth class covers an area of $6.50 \mathrm{~km}^{2}$. When the spatial analysis results of soil slope classes are examined, it is seen that the largest surface area is between $3-6 \%$ slope and this area is $8022.80 \mathrm{~km}^{2}$. It has been determined that the areas in the $30-45 \%$ slope class have the smallest surface area and the total of these areas is $5.21 \mathrm{~km}^{2}$. In terms of erosion classification, the lands in Kayseri province are classified as II. classified as areas of high erosion risk. When evaluated in terms of large soil groups, it has been determined that generally limeless brown soils are dominant and the total amount of these areas is $6156.54 \mathrm{~km}^{2}$. It has been determined that the area covered by brown forest soils has a very small share in the whole area. Considering other soil properties, it was determined that slightly salty soils cover a very small area $\left(0.99 \mathrm{~km}^{2}\right)$. It has been determined that stony soils cover an area of $8600.58 \mathrm{~km}^{2}$. As a result of the study, spatial distribution maps were created showing soil depth, slope
\end{abstract}

and erosion classes, large soil groups and other soil characteristics of Kayseri province, which will guide the investor organizations in the region.

Keywords Geography Information Systems (GIS), Land Slope, Soil Depth, Erosion Classes, Large Soil Groups, Some Soil Properties, Kayseri Province, Turkey

\section{Introduction}

Nutrition is the most important need of humankind since its existence. As in other countries, the rapidly increasing population in Turkey by utilizing limited natural resources; Sufficient precautions should be taken in order to have an adequate, balanced and healthy diet. One of the most important factors affecting the yield in agricultural production is soil fertility. Increasing the amount of product to be taken from the unit area of the soil depends on a good soil management [1].

The main factor of agricultural production is soil. As long as the fertility of the soil is at an appropriate level, the amount and quality of the product to be taken from the unit area will be high. Therefore, it is extremely important to increase and protect the productivity levels of soils.

Soils with suitable physical, chemical and biological 
properties as well as containing sufficient and balanced plant nutrients are considered as fertile soils. Therefore, a wide variety of factors are taken into account when assessing soil fertility status. Soil fertility depends on many factors and application methods [2].

The world has an area of 510 million $\mathrm{km}^{2}$. Water covers $2 / 3$ of this area. $1 / 3$ of it covers land areas [3]. Turkey's total surface area is $783,577 \mathrm{~km}^{2}$, in other words, it is 78 million hectares. When the dam and natural lakes are removed, the remaining area is $769,600 \mathrm{~km}^{2}$.

Mountains cover more than half of Turkey's territory. The remaining part is plain, plateau, rough terrain and flat hills. Turkey's 190,000 $\mathrm{km}^{2}$ area consists of plains of different heights, which are covered with alluvium. Plateaus cover an area of $80,000 \mathrm{~km}^{2}$. The sum of the plains and plateaus corresponds to an area of $270,000 \mathrm{~km}^{2}$, which is $1 / 3$ of the surface area of Turkey [4].

It can be said that there are $370,000 \mathrm{~km}^{2}$ of plains in Turkey, apart from the mountainous areas, with $100,000 \mathrm{~km}^{2}$ of rough and flat hills that are relatively easy to cultivate. The total of agricultural lands is $280,000 \mathrm{~km}^{2}$, that is, around 28 million hectares. The agricultural area in Turkey is 28.05 million hectares. The irrigable agricultural area is 25.75 million hectares. Dry farming area is 7.25 million hectares and irrigated area is 5.90 million hectares [4].

For land users and managers concerned with the conservation of land resources, rational and sustainable land use is an important issue for the benefit of present and future populations [5].

In Turkey, the task of taking the inventory of soil resources, protecting, developing and ensuring their sustainable use was first given to the General Directorate of Soil water, which was established in 1960 [6].

Interpolation methods are applied in the evaluation of the data transferred to the computer and classified according to certain criteria in GIS, and the measured geographical data is spread over the whole area with spatial interpolation techniques and distribution maps of the area are obtained [7].

Three different types of data are used in GIS: temporal, thematic and spatial. Temporal data indicates the time of data collected, thematic data indicates the subject and spatial data indicates the location of the data in the world [8]. GIS enables to work effectively with large amounts of data [9].

This database is used in agricultural planning, modeling of environmental impacts, in various engineering branches, and in the planning and conservation of natural resources. The accuracy, detail and richness of the additional information contained in the reports provide valid results for subsequent uses for this purpose [10].

This study includes important information that will shed light on the strategies that can be formed in terms of agricultural areas and soil fertility regarding the soil data of Kayseri province. In this research carried out within the scope of Kayseri province in the Central Anatolia region, large soil groups, slope and erosion status of the region and the areal distribution of soil depths were revealed by using Geography Information Systems (GIS).

\section{Materials and Methods}

The Kayseri province in Turkey which is the study area, is located in the Middle Kizilırmak section, where the southern part of the Central Anatolia Region and the Toros Mountains converge. It is located between $37^{\circ} 45^{\prime}$ and $38^{\circ} 18^{\prime}$ north latitudes and 34 $56^{\prime}$ and 36 $58^{\prime}$ east longitudes. It is surrounded by Sivas in the east and northeast, Yozgat in the north, Nevşehir in the west, Niğde in the southwest, Adana and Kahramanmaraş provinces in the south. The area of the province is $17,109 \mathrm{~km}^{2}$. While the province of Kayseri consists of 16 districts, namely Akkışla, Bünyan, Develi, Hacılar, İncesu, Kocasinan, Melikgazi, Pınarbaşı, Sarıŏlan, Sarız, Tomarza, Yahyalı, Talas, Özvatan, Felahiye and Yeşilhisar, there are 395 villages connected to the province and district. The most important and highest mountain of Kayseri is the Erciyes Mountain with a height of 3,916 meters. Erciyes Mount is an extinct cluster volcano with many secondary volcanic peaks on its chest and skirts. The important lakes of the province are Camız Lake, Çöl Lake, Sarıöl, Yay Lake and Tuzla Lake. Besides these, there are dams and ponds of various sizes. The main river of the province is Kizilırmak. In many parts of Kayseri, the steppe climate is dominant. Here, summers are hot and dry, winters are cold and snowy. However, since there are mountainous places, plains and boats between them, some climatic features given by the altitude are also effective. In the territory of Kayseri, steppe vegetation is dominant in the mountain and hilly areas as well as in the plains [11]. The location and location of the province of Kayseri, which is the subject of the research, is shown in Figure 1.

The study was carried out using 1/25.000 scaled digital soil maps prepared by the Turkey General Directorate of Rural Services [12]. The classifications of the layers used in the numerical soil data of Kayseri province are shown in Table 1. 


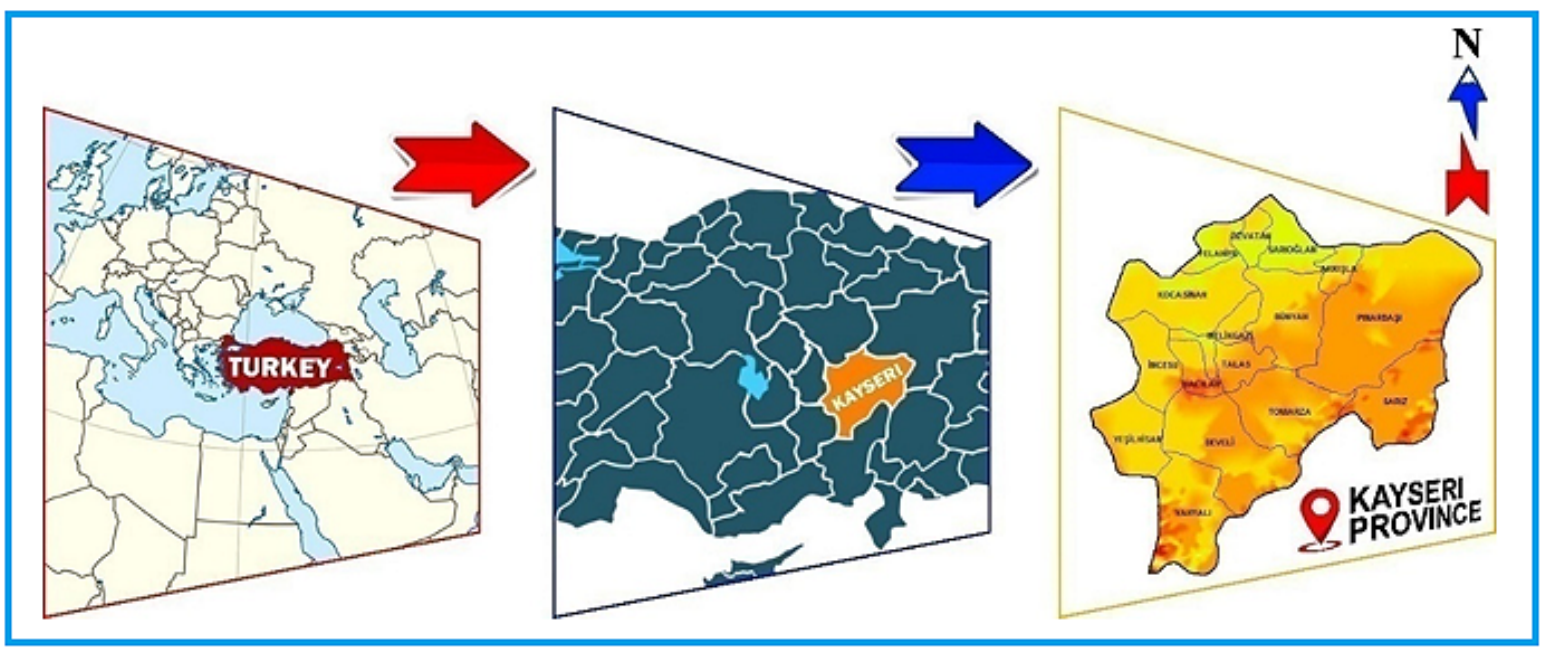

Figure 1. The Location of the Research Area

Table 1. Digital soil layers used in spatial analysis [13]

\begin{tabular}{|c|c|c|c|c|}
\hline \multicolumn{2}{|c|}{ Large Soil Groups } & \multicolumn{3}{|c|}{ Soil Depts (cm) } \\
\hline A & Alluvial Soils & A & $150>$ & Deep \\
\hline B & Brown Soils & B & $90-150$ & Medium Deep \\
\hline $\mathrm{CE}$ & Chestnut Color Soils & $\mathrm{C}$ & $50-90$ & Shallow \\
\hline $\mathrm{F}$ & Reddish Brown Soils & $\mathrm{D}$ & $20-50$ & Very Shallow \\
\hline $\mathrm{H}$ & Hydromorphic Soils & $\mathrm{E}$ & $0-20$ & Litozolik \\
\hline $\mathrm{U}$ & Limeless Brown Soils & \multicolumn{3}{|c|}{ Erosian Degree } \\
\hline $\mathrm{K}$ & Colluvial Soils & I & \multicolumn{2}{|c|}{ Light Surface Erosian } \\
\hline $\mathrm{L}$ & Regosols & II & \multicolumn{2}{|c|}{ Medium Suface Erosian } \\
\hline M & Brown Forest Soils & III & \multicolumn{2}{|c|}{ Severe Surface Erosian } \\
\hline $\mathrm{N}$ & Limeless Brown Forest Soils & IV & \multicolumn{2}{|c|}{ Very Severe Surface Erosian } \\
\hline $\mathrm{O}$ & Organic Soils & & & \\
\hline & Slope (\%) & \multicolumn{3}{|c|}{ Other Soil Properties } \\
\hline $0-2$ & Straight & \multicolumn{3}{|c|}{ Poorly Drained } \\
\hline $3-6$ & Slight Slope & \multicolumn{3}{|c|}{ Less Salt } \\
\hline $7-12$ & Medium Slope & \multicolumn{3}{|c|}{ Alkaline } \\
\hline $13-20$ & Steep Slope & \multicolumn{3}{|c|}{ Less Drained } \\
\hline $20-30$ & Very Steep Slope & \multicolumn{3}{|c|}{ Rocky } \\
\hline $30-45$ & Craggy Slope & \multicolumn{3}{|c|}{ Salty } \\
\hline & & \multicolumn{3}{|c|}{ Stony } \\
\hline & & \multicolumn{3}{|c|}{ Stony - Alkaline } \\
\hline
\end{tabular}




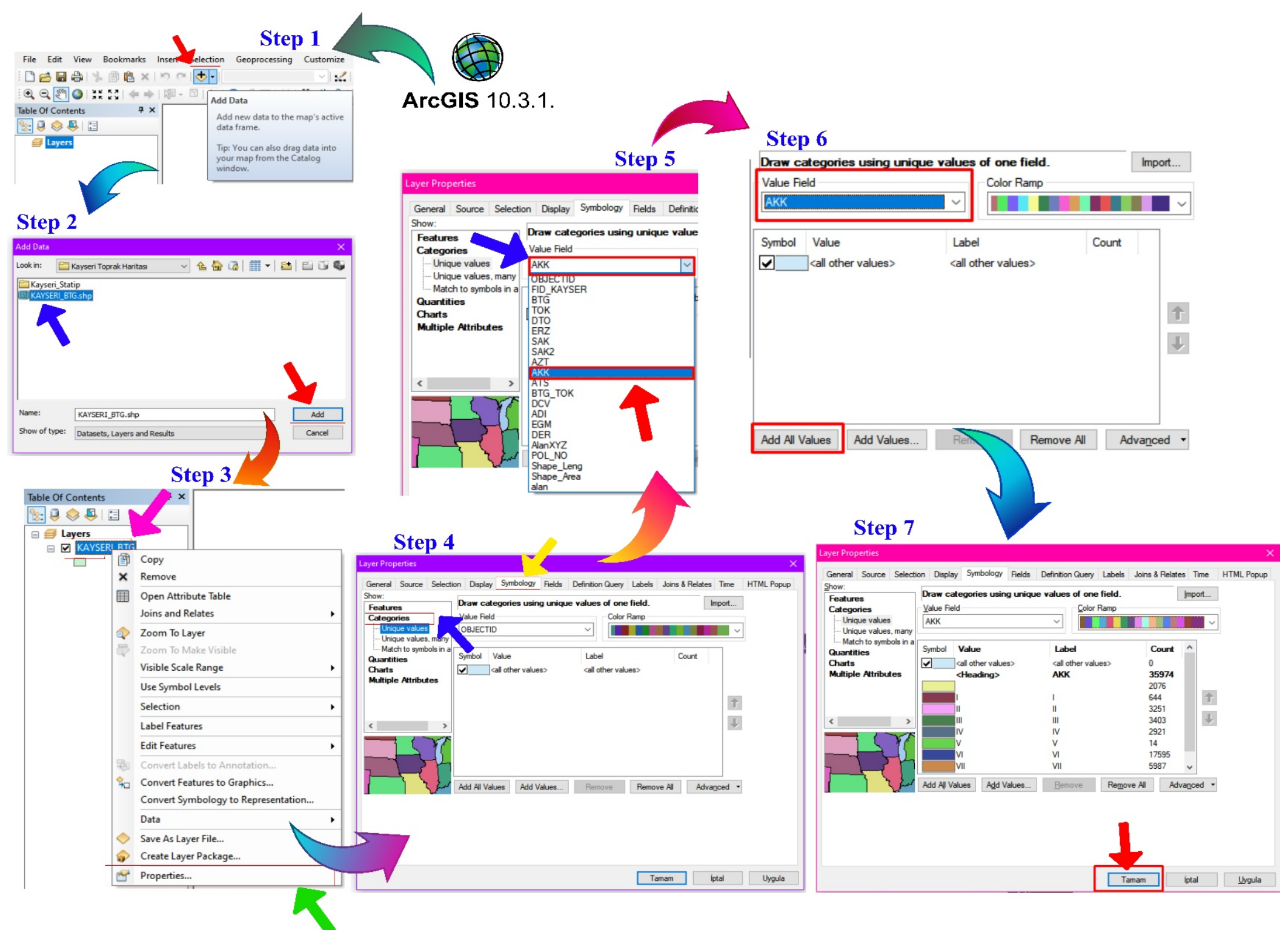

Figure 2. Spatial Analysis Steps of Digital Soil Data in Arc GIS 10.3.1 software 
In the study, Arc GIS 10.3.1 software, which is one of the Geography Information Systems software, was used for spatial evaluation of digital terrain features. It is the main component of a suite of geospatial processing programs and is primarily used to view, edit, create, and analyze geospatial data [14]. Within the scope of the study, spatial distribution maps showing soil depth, slope and erosion classes, large soil groups and other soil characteristics of Kayseri province were created. Within the scope of the research, the steps of the evaluation of the digital soil properties in the Arc GIS software are presented in Figure 2 by schematizing.

\section{Research Findings}

Soil depth, land slopes, erosion classes, large soil groups and some soil properties layers were analyzed spatially by using digital soil maps of Kayseri province and the results are presented below under headings.

\subsection{Spatial Analysis of Soil Depth Classes}

The distribution of soil depth classes obtained in the spatial analysis results made in Arc GIS software using digital soil maps of Kayseri province is given in Figure 3.

When we look at the soil depth classes in Kayseri province, ranges are given for depth limits instead of single numbers; The same depth has different effects on different soils. Class A soil depth is called very deep.
The area covered by soils with a depth greater than 150 cm was calculated as $1788.44 \mathrm{~km}^{2}$.

Class B class soil depth is called deep. The area covered by the soils with a depth of $90-150 \mathrm{~cm}$ is 1019.25 $\mathrm{km}^{2}$.

Class C soil depth is called medium deep. Soils with a depth of 50-90 cm cover an area of $9443.95 \mathrm{~km}^{2}$. Class D soil depth is called shallow. Its depth is $20-50 \mathrm{~cm}$ and the area it covers is $4175.31 \mathrm{~km}^{2}$. Class E class soil depth is called very shallow. The area of soils with a depth of $0-20 \mathrm{~cm}$ was calculated as $6.50 \mathrm{~km}^{2}$.

\subsection{Spatial Analysis of Land Slope Classes}

The spatial distribution of the land slope classes obtained in the results of the spatial analysis performed in the GIS software using digital soil maps of Kayseri province is shown in Figure 4.

The land slope of Kayseri province consists of $0-2 \%$ slope class flat and nearly flat areas. The area covered by the soils of this class is $1545.81 \mathrm{~km}^{2}$. Slightly sloping areas are in the $3-6 \%$ slope group and cover an area of $8022.80 \mathrm{~km}^{2}$. The area of $4358.27 \mathrm{~km}^{2}$ consists of lands with a slope of $7-12 \%$. Areas with steep slopes are lands with a slope of $13-20 \%$. There is a land of $1501.60 \mathrm{~km}^{2}$ in this slope group. Areas between $21-30 \%$ are very steep sloping lands and cover an area of $939.75 \mathrm{~km}^{2}$. The lands between $31-45 \%$ are steep sloping areas, and an area of approximately $5.21 \mathrm{~km}^{2}$ in Kayseri is classified as steep sloping land.

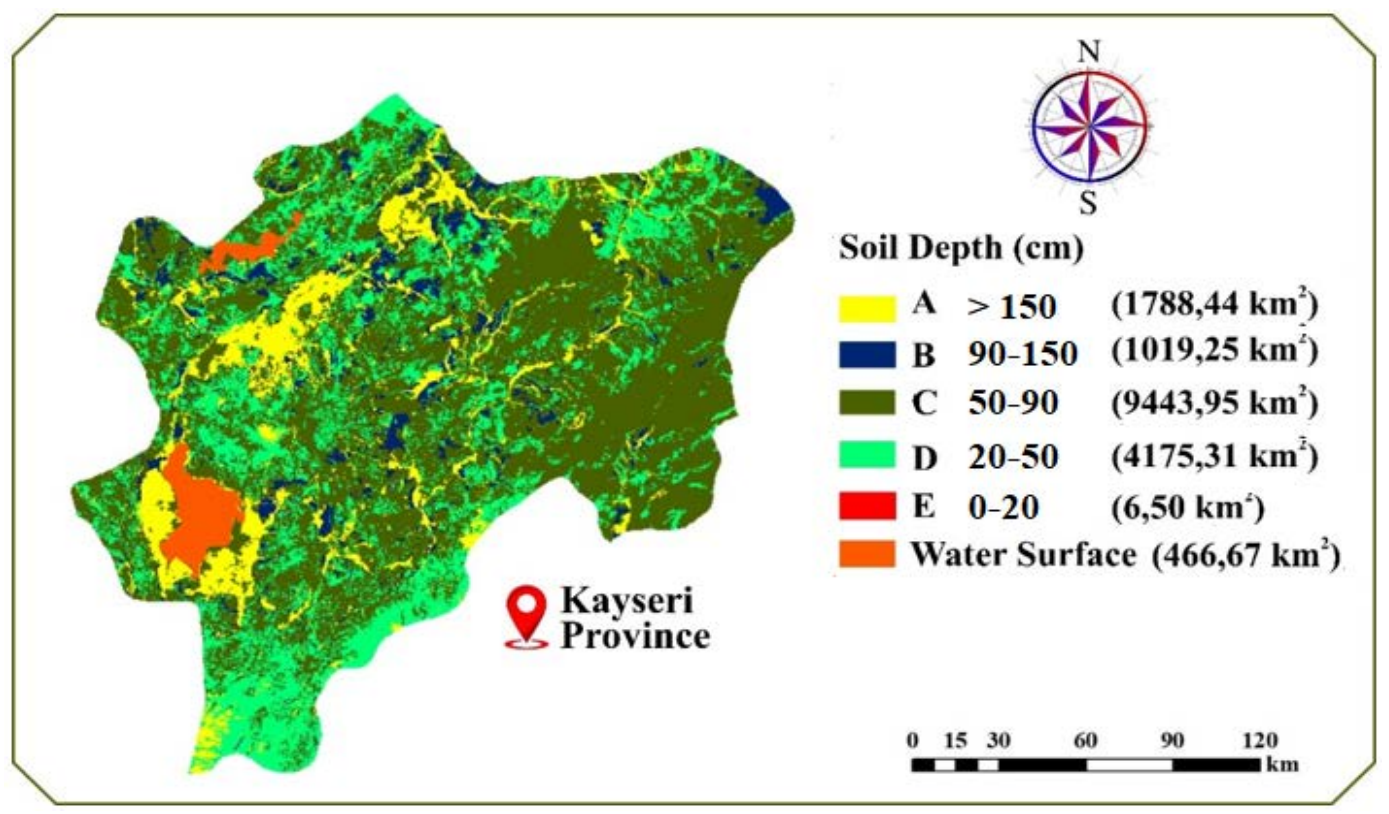

Figure 3. Spatial Analysis of Soil Depth Classes 


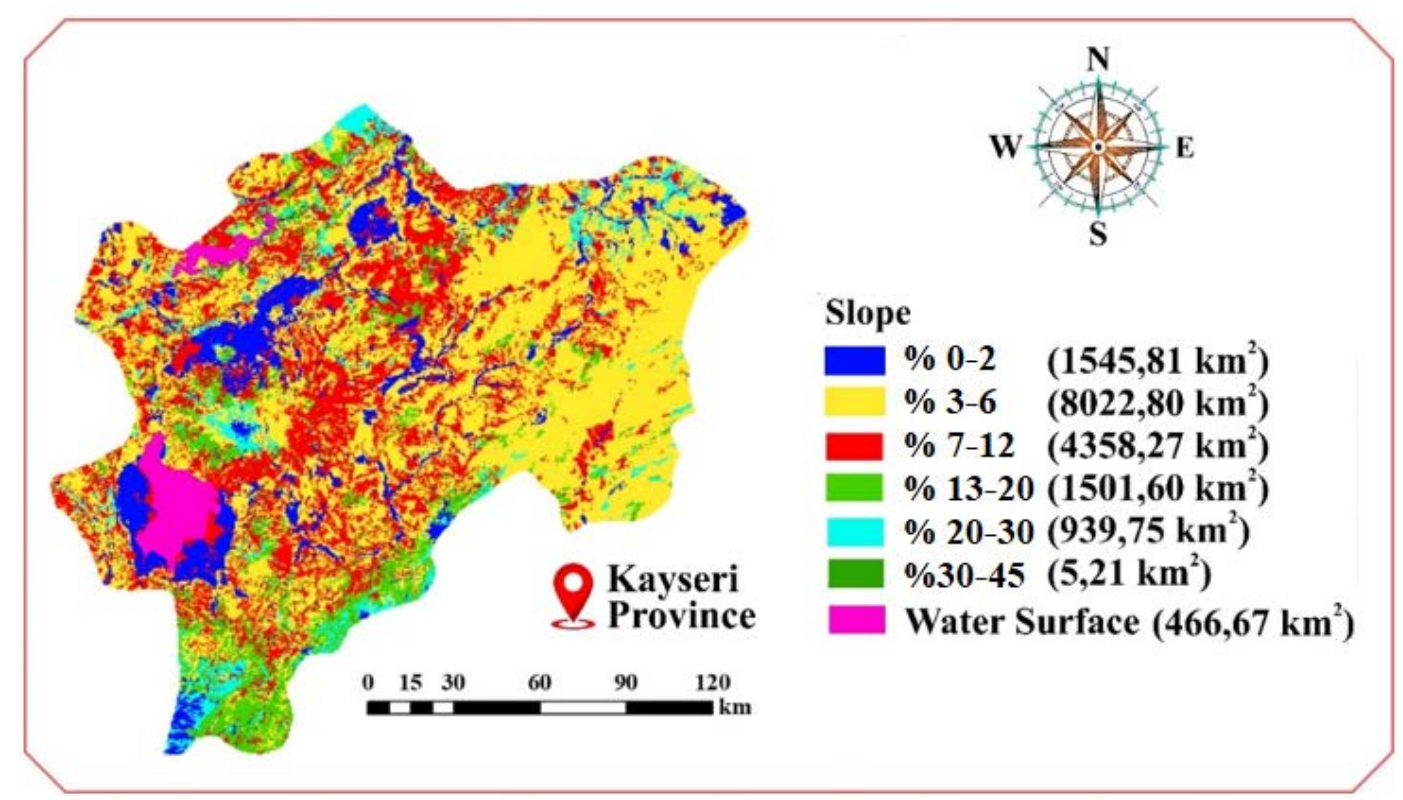

Figure 4. Spatial Analysis of Land Slope Classes

\subsection{Spatial Analysis of Erosion Classes}

The distribution of the land erosion classes obtained in the spatial analysis results made using digital soil maps of the province of Kayseri province is given in Figure 5.

Erosion class I is called no or slight erosion. No erosion damage or less than $25 \%$ of the driven coat's horizon is gone. Its surface area is $1532.36 \mathrm{~km}^{2}$. Erosion class II is called intermediate erosion. $25-75 \%$ of the plowed soil layer or horizon is damaged. Its surface area is $8759.84 \mathrm{~km}^{2}$. Erosion class III is called severe erosion. More than $75 \%$ of its horizon has been exposed to erosion. Its surface area is $5194.23 \mathrm{~km}^{2}$. Erosion class IV is called very severe erosion. $25-75 \%$ of the soil layer is damaged. Its surface area is $951.01 \mathrm{~km}^{2}$.

\subsection{Spatial Analysis of Large Soil Groups}

The spatial distribution of the large soil groups of Kayseri province is shown in Figure 6.

According to the results of the spatial analysis of the large soil groups in Kayseri, alluvial soils are usually formed on fresh sedimentary deposits and these young soils do not have or, if present, are very poorly developed; on the other hand, there are mineral layers with different properties. The area covered by alluvial soils is $1324.81 \mathrm{~km}^{2}$.

Brown soils are mostly found in arid and semi-arid climates. The natural vegetation on them consists of short grass and bushes. They contain a large amount of calcium in their profile. They are rich in plant nutrients. Natural drainage is good. Their color, as their name suggests, is brown. The surface area covered by brown soils is $3182.15 \mathrm{~km}^{2}$.
Chestnut soils are rich calcareous soils. Unlike brown soils, there is no lime in the upper layer and the color is darker. The lime accumulation layer in these is deeper than in Brown soils and the amount of clay is higher. The surface area of chestnut soils is $131.66 \mathrm{~km}^{2}$.

Except for the color, reddish brown soils have almost all the same or similar properties of brown soils. They are found in arid and semi-arid climates. The natural vegetation is grass and bushes. Natural drainage is good. Biological activity is low in these soils. Natural yields are high. The surface area of reddish-brown soils is $1351.56 \mathrm{~km}^{2}$.

Hydromorphic soils are characterized by excessive soil moisture. Drainage is often poor due to profile characteristics that prevent normal water infiltration or because the soil is located in a slumped area. The large soil groups in this suborder have different characteristics from each other. The surface area of hydromorphic soils is $3.60 \mathrm{~km}^{2}$.

Non-calcareous brown soils, the topsoil is soft or somewhat firm. Subsoil is heavier and harder. Although lime is washed away, the reaction is neutral or alkaline. Natural drainage is good. The natural vegetation is mixed forest or heather with shrubs and grasses. The surface area of non-calcareous brown soils is $6156.54 \mathrm{~km}^{2}$.

Collivial soils, deposited on the slopes of steep slopes by gravity, landslides, runoff, or transported from short distances by side streams, and formed on material called collivium, these soils are young and have characteristics more similar to those of the surrounding upper land soils. The surface area of collivial soils is $42.57 \mathrm{~km}^{2}$.

Regosols are very sandy, low water holding capacity, highly permeable shallow soils formed on loose and unconnected deposits. 
They have an underdeveloped profile. Plant roots can penetrate into the main material. Some of these lands are cultivated. The surface area of the regosols is $678.98 \mathrm{~km}^{2}$.

Brown forest soils were formed on the main material with high lime content. They have poorly developed layers. Their reaction is neutral or alkaline. Lime deposits are seen in the lower parts of the subsoil. Drains are good. The surface area of brown forest soils is $4.42 \mathrm{~km}^{2}$.

Limeless brown forest soils have a dark layer on top and a slightly different layer on the bottom. Soils are lime-free and the reaction is acid, neutral or calcareous.
Their natural efficiency is not much. The surface area of the non-calcareous brown forest soils is $18.88 \mathrm{~km}^{2}$.

Organic soils were formed in areas with concave topography with high groundwater and no outflow or in old shallow lakes.

Organic soils have emerged as a result of the slow decomposition of roots, stems and leaves of water-loving plants such as reeds, reeds and buckets in high ground water, under anaerobic conditions. The surface area of organic soils is $3535.27 \mathrm{~km}^{2}$.

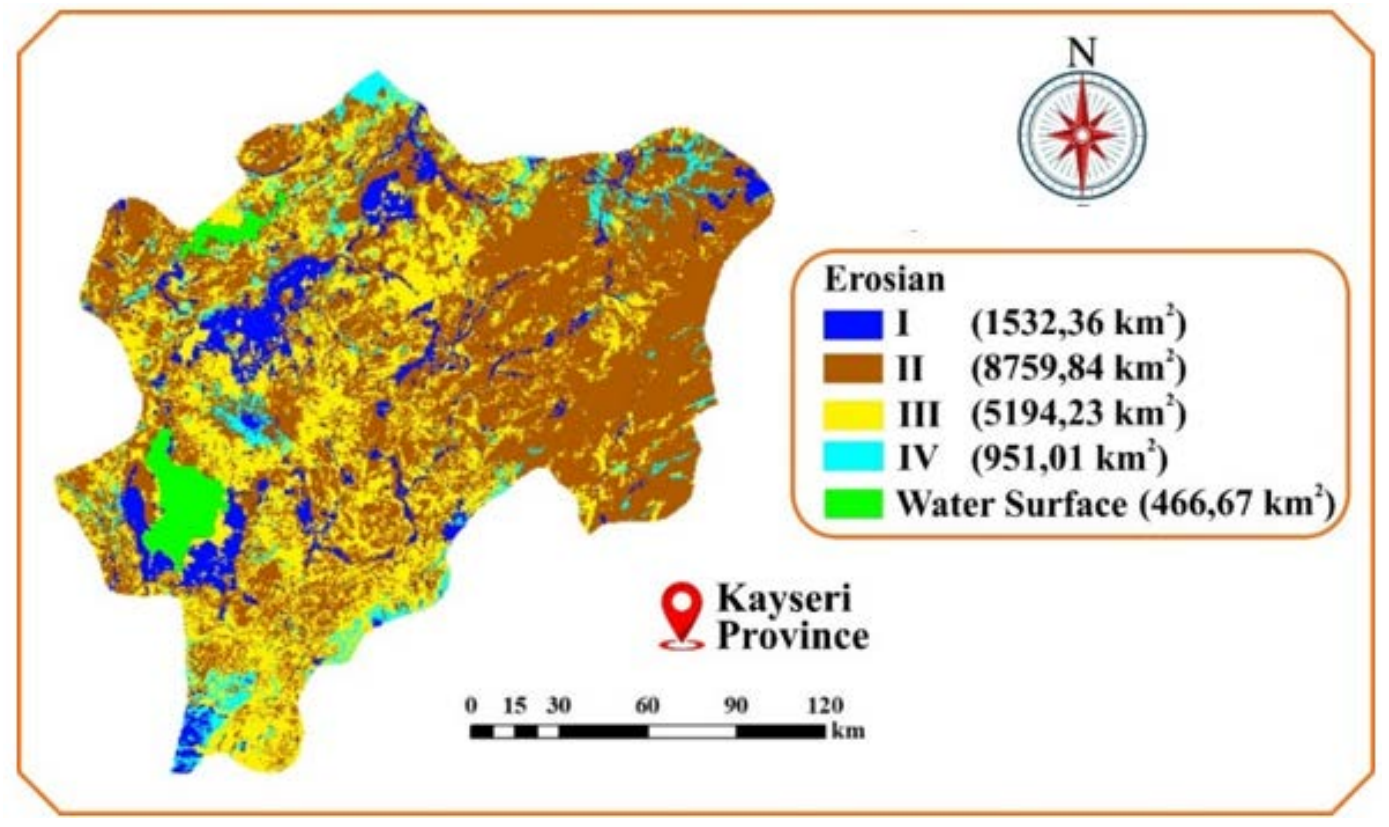

Figure 5. Spatial Analysis of Erosian Classes

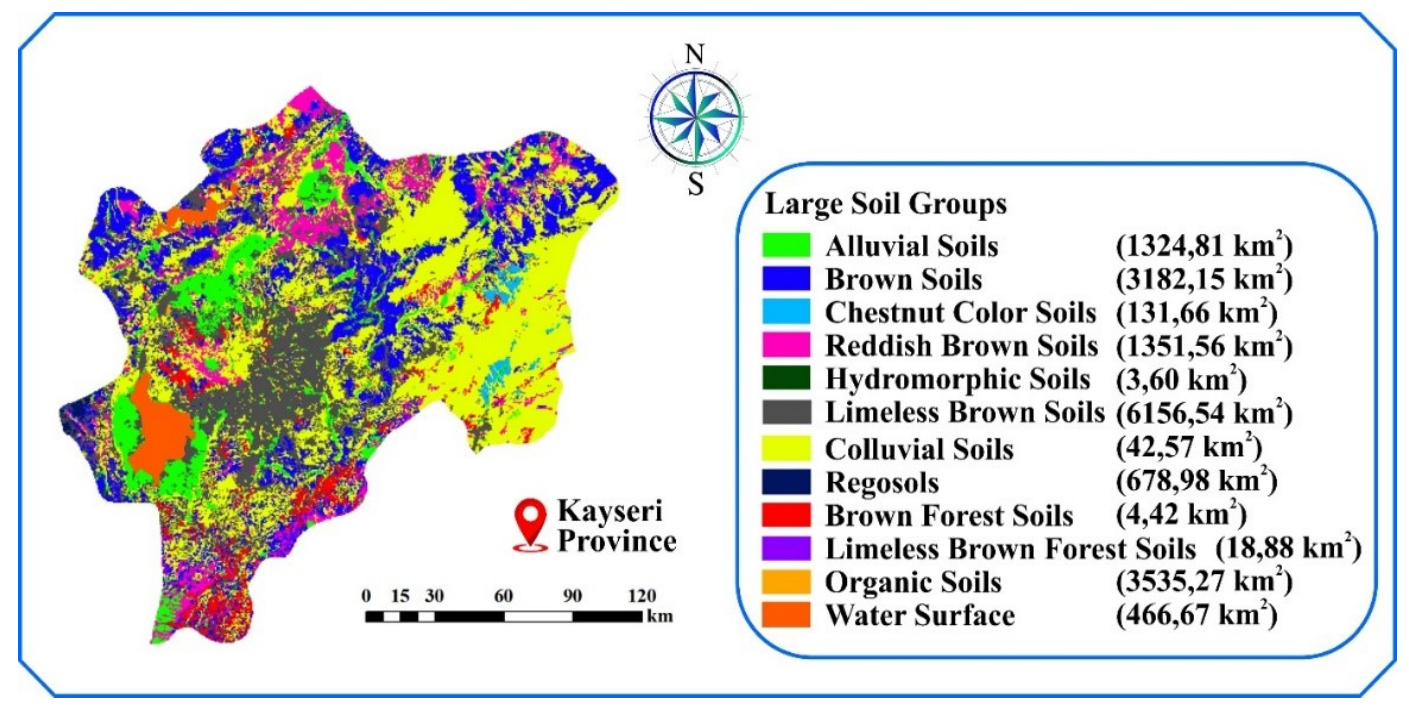

Figure 6. Spatial Analysis of Large Soil Groups 


\subsection{Spatial Analysis of Some Soil Properties}

The spatial distribution of the other soil properties is shown in Figure 7 and analyzed using digital soil map of Kayseri province. Considering the spatial analysis of other soil properties of Kayseri province, the area covered by poorly drained soils is $42.08 \mathrm{~km}^{2}$. The surface area covered by slightly salty soils is $0.99 \mathrm{~km}^{2}$. The surface area of poorly drained soil with mild salinity is $17.42 \mathrm{~km}^{2}$. The surface area of poorly drained soil with mild salinity is $114.23 \mathrm{~km}^{2}$. The surface area of poorly drained soil with its alkaline feature is $14.97 \mathrm{~km}^{2}$. In addition to its alkaline feature, the surface area covered by insufficiently drained soil is $39.92 \mathrm{~km}^{2}$.
The surface area of the rocky soil is $1322.19 \mathrm{~km}^{2}$. The surface area of salty soil is $20.10 \mathrm{~km}^{2}$. The surface area of poorly drained soil with salinity is $8.14 \mathrm{~km}^{2}$.The surface area covered by poorly drained soil with salinity is $9.25 \mathrm{~km}^{2}$. The surface area of stony soil is $8600.58 \mathrm{~km}^{2}$.

The surface area of stony and alkaline soil is $0.02 \mathrm{~km}^{2}$. The surface area of poorly drained soil together with stony and alkaline soil is $14.58 \mathrm{~km}^{2}$. The surface area of poorly drained soil together with stony and alkaline soil is $5.80 \mathrm{~km}^{2}$. The surface area of poorly drained soil is $180.91 \mathrm{~km}^{2}$. The surface area of other areas is $6544.65 \mathrm{~km}^{2}$.

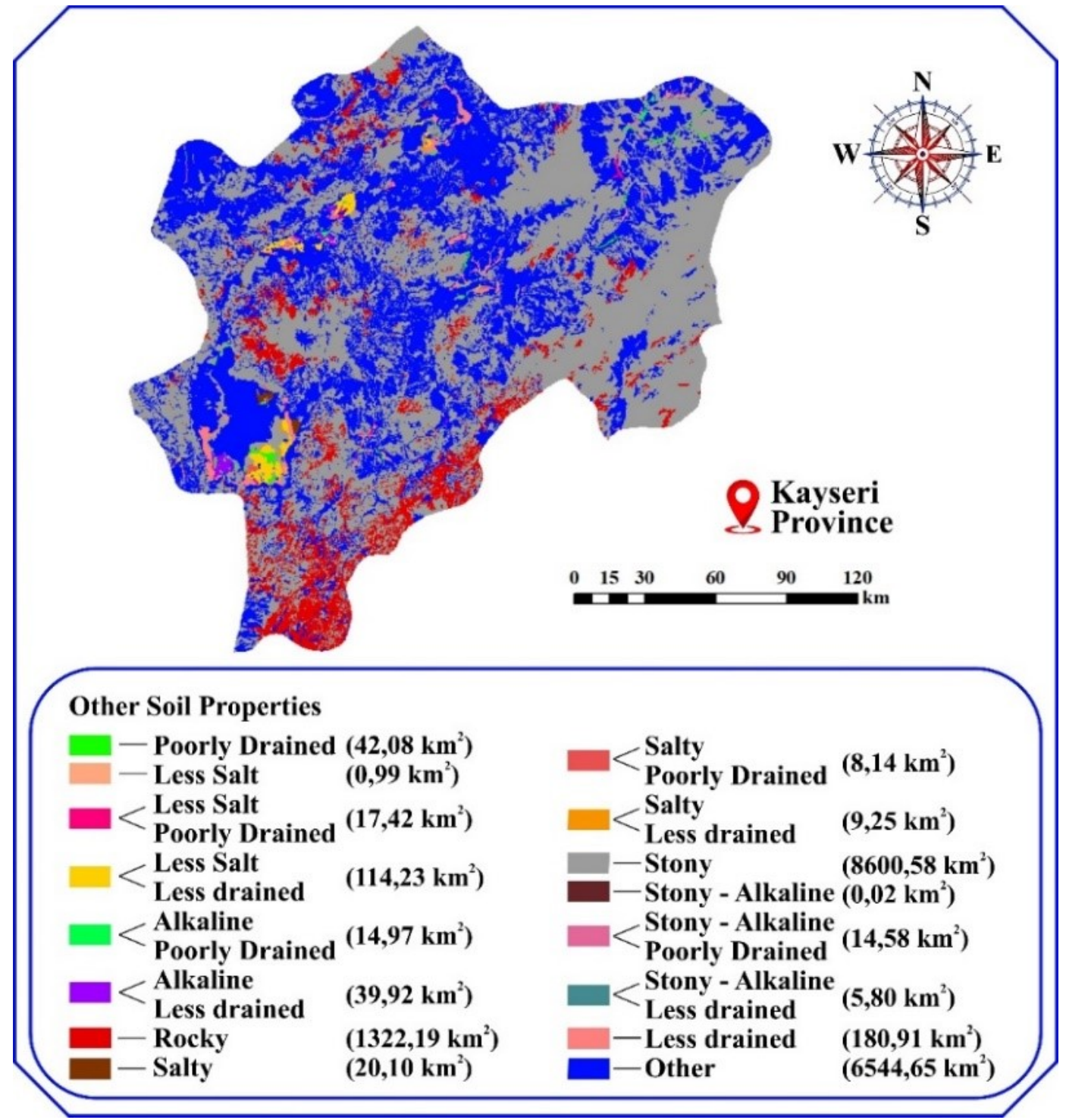

Figure 7. Spatial Analysis of Some Soil Properties 


\section{Conclusion and Recommendations}

Turkey is under serious threat from the effects of climate change as it is located in the Mediterranean Belt, which is one of the sensitive zones in the climate change process. Carbon emission from the soil is directly related to climate change and has an important relationship with the soil organic carbon pool [15]. Some soil properties of Kayseri province were analyzed spatially by using the Geography Information Systems. The spatial distributions of the soil properties revealed as a result of the research are summarized in Figure 8 and presented in a schematic form.

In line with the soil, chemical, biological and physical properties; It is one of the important components of terrestrial ecosystems because it both stores the plant nutrients required for plant production and filters or retains pollutants that have negative effects on the environment [16].
In order to provide food to the growing population in the world, larger land resources are needed and the land is started to be used intensively for overproduction. On the other hand, as a result of the pressure of the increasing population, deterioration in fertile soil resources and spatial losses as a result of construction show their effects [17].

In another study conducted in Kırşehir province, large soil groups, land uses, soil depth classes, land slopes and soil erosion classes were spatially analyzed by using GIS As a result, spatial distribution maps of some soil and land characteristics of Kırşehir province were created [18].

Geography Information Systems (GIS) is an information system created for collecting, entering, storing, querying, spatial analysis, displaying and outputting spatial information (graphics and attributes) in computer environment [19].

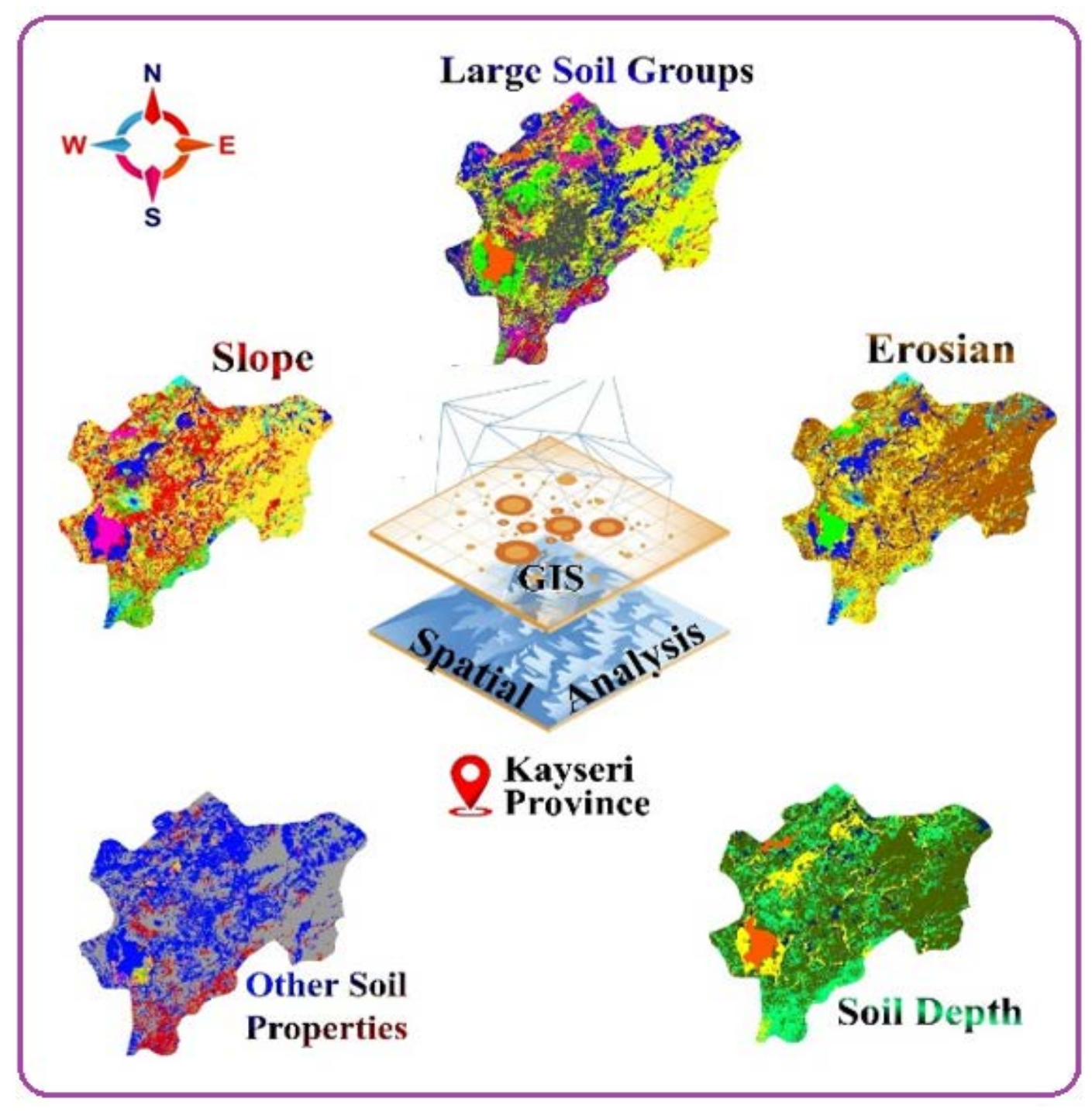

Figure 8. Spatial analysis database of soil properties in Kayseri Province 
While GIS was developed for computer aided map assembly in the early 1960s, it has turned into a technology that serves different purposes in many fields today [20].

The spatial evaluation of soil properties in the GIS software and the presentation of the results based on maps will allow the visual evaluation of soil distribution in the field. It will be inevitable that the results obtained will make significant contributions to the agricultural production activities to be carried out in the province of Kayseri province.

\section{REFERENCES}

[1] Ateş K., Turan V., "Bingöl İli Merkez İlçesi Tarım Topraklarının Bazı Özellikleri ve Verimlilik Düzeyleri”, Türkiye Tarımsal Araştırmalar Dergisi, 2(2):108-113. 2015. (inTurkish) https://www.acarindex.com/pdfler/acarindex-1 c7589fa-5ed5.pdf

[2] Başar H., "A Study on Determination of Fertility Status of the Soils by Soil Analysis in the Bursa Province”, Uludag Üniv. Ziraat Fak. Derg., 15:69-83, 2001. https://dergipark. org.tr/tr/download/article-file/153940

[3] Sekin S., "Dünya Tatlı Su Rezervlerinin Coğrafi Dağılımı" Marmara Geographical Review, 1:247-256, https://dergipark.org.tr/en/pub/marucog/issue/448/559711 Access Date: (13.07.2021), 2013 (in Turkish)

[4] Anonymous, "Türkiye Toprak ve $\mathrm{Su}$ Kaynakları", http://www.dsi.gov.tr/toprak-ve-su-kaynaklari Access Date: (08.04.2020), 2014. (in Turkish)

[5] Dengiz O., Gülser C., İç S., Kara Z., “Așağı Aksu Havzası Topraklarının Fiziksel ve Kimyasal Özellikleri ve Haritalanması", Anadolu Tarım Bilimleri Dergisi, 24(1):34-43,2009.(inTurkish) https://dergipark.org.tr/en/do wnload/article-file/187723

[6] Dengiz O., Sarığlu E.F., "Samsun İlinin Potansiyel Tarım Alanlarının Genel Dağılımları ve Toprak Etüd ve Haritalama Çalışmalarının Önemi”, Anadolu Tarım Bilimleri. Dergisi, 26(3):241-250, 2011 (inTurkish) https://dergipark.org.tr/en/download/article-file/187455

[7] Heuvelink G.B.M,, "Incorporating Process Knowledge in Spatial Interpolation of Enviromental Variables, Lisbon, Portugal”, 7th Inernational Symposium on Spatial Accuracy Assessment in Natural Resources and Enviromental Sciences, 2006. https://citeseerx.ist.psu.edu/ viewdoc/download?doi=10.1.1.572.8018\&rep=rep1\&type $=\mathrm{pdf}$

[8] Heywood I., Cornelius S., Carver S., “An Introduction to Geographical Information Systems”, Longman, p.11-12, 199, New York, 2005.
[9] Suri M., Hofierka J., "Soil Water Erosion Identification Using Satellite and DTM Data”. http://libraries.maine.edu/ Spatial/gisweb/spatdb/egis/eg94106.html. 1994.

[10] Rogowski A.S., Wolf K.J., "Incoporation Variability into Soil Map Unit Delineation”, Soil Sci. Soc. Am. J. 58:163-174, https://doi.org/10.2136/sssaj1994.0361599500 $5800010024 x 1994$.

[11] Anonymous., "Kayseri Hakkında", Çevre ve Şehircilik Bakanlığ1,Türkiye, https://kayseri.csb.gov.tr/ilimiz-hakkin da-i-768 Access Date: (11.04.2020), 2018.

[12] Anonymous., "Sayısal Toprak Haritaları”, Mülga Köy Hizmetleri Genel Müdürlüğü, Ankara, 2000. (in Turkish)

[13] Anonymous., "Toprak ve Arazi Sinıflaması Standartları TeknikTalimatı",https://www.mevzuat.gov.tr/MevzuatMet in/1.5.5403.pdf Access Date: (16.04.2020), 2005. (in Turkish)

[14] Anonymous, “ArcMap” https://en.wikipedia.org/wiki/Arc Map\#cite_note-20 Access Date: (12.04.2020), 2015.

[15] Sönmez B., Özbahçe A., Akgül S., Keçeci M.. “Türkiye Topraklarının Bazı Verimlilik ve Organik Karbon (TOK) İçeriğinin Coğrafi Veritabanının Oluşturulması”, Tarım ve Orman Bakanlığı, Tarımsal Araştırmalar ve Politikalar Genel Müdürlüğü Proje Sonuç Raporu TAGEM (Vol. 13). TSKAD/11, 2018 (in Turkish)

[16] Marzaioli R., R D’Ascoli., De Pascale R.A.., Rutigliano F.A., "Soil Qquality in a Mediterranean area of Southern Italy as related to different land use types” Applied Soil Ecology 44: 205-212, 2010. https://www.sciencedirect.co m/science/article/pii/S0929139309002157?casa_token=wL z17dPGI3gAAAAA:yMuWRugFZekhNIXqhKwqaIeoMY deW98RHMKGq4up7nZ2qdmgZLUCe0-EyWtqhSVqV0 RXbDnb

[17] Çullu M.A., “Toprak Etüt Haritalama ve Toprak Yönetimi Gerekliliği”, Toprak Bilimive Bitki Besleme Dergisi. 1(1):23-25, 2012. (inTurkish) https://toprak.org.tr/files/der gi_sayilari_CG6E23EX.pdf\#page=27

[18] Bağdatlı, M. C., Arslan, O., 2020. GIS Mapping of Large Soil Groups, Current Land Use, Soil Depths and Slopes, Soil Erosian in Kirsehir Province of Turkey, World Research Journal of Agricultural Science (WRJAS), 8(1):265-277 https://premierpublishers.org/articles/05112 0203508. DOI: $10.5281 /$ zenodo.4334128

[19] Aranoff S, Geographical Information Systems: A Management Perspective, WDL Publications, Ottawa, Canada, 1989. https://www.tandfonline.com/doi/abs/10.10 80/10106048909354237, DOI:10.1080/101060489093542 37

[20] Yomralığlu T., "Coğrafi Bilgi Sistemleri Temel Kavramlar ve Uygulamalar", Akademi Kitabevi, 2. Bask1, 2000. (in Turkish) 